\title{
Enhancing Municipal Capacities: From Emergency Response to Planning Marwa Boustani
}

\begin{abstract}
The paper explores the capacities and roles of Municipalities and Unions of Municipalities (UoMs) as actors and contributors to regional planning in Lebanon, and their role in addressing needs caused by the Syrian refugee crisis, especially related to service provision and shelter. The paper discusses the potential of strengthening local capacities, based on the experience of the United Nations Human Settlements Programme (UN-Habitat) through establishing Regional Technical Offices (RTOs) within Unions of Municipalities in Lebanon. It also addresses the challenges faced by UoMs and Municipalities due to the arrival of Syrian refugees to a context with weak national governance. The paper is based on interviews with key municipal actors to better understand their role in coordinating the work of various local and international actors in the response.
\end{abstract}

Keywords: Unions of Municipalities, Local Authorities, Planning \& Emergency Response, Local Governance

To cite this paper: Marwa Boustani, "Enhancing Municipal Capacities: From Emergency Response to Planning ", Civil Society Knowledge Center, Lebanon Support, July, 2014 . DOI:

10.28943/CSR.001.004.

[ONLINE]:

https://civilsociety-centre.org/paper/enhancing-municipal-capacities-emergency-response-planning

\section{Introduction}

The turmoil in Syria led to the highest number of simultaneously displaced persons in history 1 , with the highest percentage of refugees residing in different areas in Lebanon, mostly in the North and the Bekaa2. The crisis poses a high level of uncertainty rendering the response more difficult to organize, as Mr. el-Daher, advisor to the Prime Minister on Economic Affairs and Development, stated: "The nature of the crisis is different, as we cannot predict how long it will last." $\underline{3}$

At the beginning of the crisis, Lebanese communities were glad to host the first wave of refugees. The prolongation of the crisis, however, exerted pressures on host communities, due to the enormous increased demand on basic services and lack of central and local government capacities, in addition to insufficient support from humanitarian actors. Pressures on the already weak infrastructure, limited access to services, decreased safety, and competition in the labor market contributed to reduced willingness to host refugees and the escalation of tensions.

Weak governance in the country and the large-scale nature of the emergency suggested the need for a well-researched and more responsive Lebanese strategy. However, the country "lacks the requirements for shaping consistent and comprehensive policies in accordance with the needs of public 
interests," $\underline{4}$ ultimately resulting in the adoption of the "disastrous policy of no-policy." $\underline{5}$

The lack of a national response strategy made it more difficult to contain the impact of the crisis on Lebanon and address the needs of almost one million refugees. While estimates by the Lebanese government point to 1.5 million Syrian refugees, The UN Refugee Agency (UNHCR) maintains that the number is closer to one million $\underline{6}$ registered refugees or persons from Syria awaiting registration in Lebanon, as of April 2014.

The response - coordinated by UNHCR - targeted the host population to a small extent. However, it did not systematically include local authorities in planning and coordination, although most agencies involved in the response consider municipalities and Unions of Municipalities (UoMs) to be relevant and reliable local partners.

However, with minimal capacities, lack of national response strategies, and limited finances, municipalities and UoMs were constrained in their approach to the optimal provision of solutions for better living conditions of both Syrian refugees and host communities. The following sections expand on relief efforts addressing Syrian refugees in Lebanon by focusing on the role of local authorities in order to propose recommendations for better future responses.

\section{Key Actors in the Emergency Response}

The government drafted a response plan on December 3, 2012, dividing up responsibilities between the Ministry of Social Affairs, the Ministry of Education, the Ministry of Health, and the Higher Relief Council. Yet, the plan was never adopted, due to the resignation of Prime Minister Najib Mikati and the long delays in forming a new cabinet7. Currently, the UNHCR and other UN agencies are coordinating the humanitarian response of international and national agencies $\underline{8}$, co-led by the Ministry of Social Affairs.

On the level of public institutions, the Directorate General of Urban Planning (DGUP) and the Council of Development and Reconstruction (CDR) - the institutions responsible for planning and large-scale development projects in Lebanon - remained passive in their response to the crisis, with the absence of a national policy urging them to intervene. However, the two public institutions possess key policymaking and planning capacities and responsibilities, which could be the foundation of sound solutions on the national level.

Consequently, municipalities and UoMs were left to deal with the fate of Syrian refugees in their localities, taking responsibility for hosting and extending basic urban services, with the financial support of international and national NGOs and agencies.

\section{Role of Municipalities and Unions of Municipalities}


Weak governance and the unstable political situation in Lebanon, rendering decision-making very difficult at the national level, caused the breakdown in public trust. In this context, Municipalities and Unions of Municipalities became the most active public institutions in responding to the Syrian refugee crisis, as they are "working on the ground and eager to intervene." 9 UN agencies such as UNHCR, International Organization for Migration (IOM) and UN-Habitat and international NGOs such as Norwegian Refugee Council (NRC) and the Danish Refugee Council (DRC), consider UoMs and municipalities to be among the most appropriate local partners in the emergency response.

The Decree-Law no.118 of 1977 entrusts municipalities with a broad range of tasks and provides them with financial and administrative autonomy. In reality, however, the administration and finances of municipalities are constrained, since $70 \%$ of the 1,100 municipalities in Lebanon are small and with limited capacities for service provision, in addition to being highly dependent on the irregular payments of the Independent Municipal Fund.

Around 750 municipalities (2/3 of the total) have jointly formed 51 Municipal Unions, enabling them to act on a larger scale and increasing their capacities. However, UoMs continue to face several challenges, such as weak administrative capabilities, inability to collect membership fees, high dependence on the Independent Municipal Fund for revenues, and overlapping competencies with individual municipalities.

The respective strengths of the UoMs, on the other hand, include the appropriate spatial representation, a good combination of tools and human capacities, exchange of experiences and competencies, a strong network which has a greater power to influence, the opportunity for smaller municipalities to grow with the support of the larger ones, and increased feasibility of developmental projects.

To build on the strengths of UoMs and municipalities and enhance their capacities, UN-Habitat established and funded Regional Technical Offices (RTOS) at the level of the Unions. Through these RTOs, UN-Habitat implemented its emergency response to address the July-2006 Israeli war on Lebanon, as well as the Syrian crisis, empowering UoMs to coordinate the response.

The RTO model is based on the "Municipal Act," specifically Article 122 of Decree-Law no. 118/1977, which specifies that the UoM's Engineering Body shall be in charge of certain tasks on behalf of the member municipalities. This includes assisting in approving applications for construction permits, preparing required technical studies and consultations, setting specifications for supplies, works, and services, and developing plans. As mentioned above, mainly fiscal challenges resulted in under capacitated and under staffed technical units within UoMs.

\section{Regional Technical Offices (RTOs) within Unions of Municipalities}

Establishing RTOs within municipality unions guarantees their involvement in emergency response and lays the foundation for RTO support in the recovery and planning phases. RTOs promote an integrated approach by collaborating with local, national and international actors in shelter, infrastructure, and community support projects. Thus, they assist municipalities in conducting rapid technical assessments, 
collecting data, technical support, implementation of development projects and eventual contribution to planning at a local and/or regional level. The RTO team is made up of qualified local engineers, field workers, urban planners, social workers, architects, administrative assistants, and so on.

In response to the July-2006 war, UN-Habitat established three RTOs in the UoMs of Tyr, Bint Jbeil, and Jabal Amel. The RTOs were supported by UN-Habitat from 2007 till 2009. They were later adopted by the UoMs and two - Bint Jbeil and Jabal Amel - are still functional today. In 2013, UN-Habitat replicated the model and initiated two RTOs in the UoMs of Sahel al-Zahrani and Iqlim al-Kharoub to respond to the impact of the Syrian refugee crisis in those areas. Both RTOs are implementing rehabilitation works to support Syrian refugees, in addition to community support projects and coordinating with municipalities, international and national NGOs, and UN agencies for a better response.

The experiences Jabal Amel RTO and Sahel El Zahrani RTO are presented below.

\subsection{The UoM of Jabal Amel:}

Jabal Amel is considered by UN-Habitat to be an exemplary case of how an RTO contributed to efficiently enable and support a UoM in emergency response through a process of recovery and planning. The RTO of Jabal Amel was set up in response to reconstruction needs in the South after the July 2006 War, to support the rehabilitation process and introduce data management tools to UoM. In 2007, the RTO was supplied with a Geographical Information System (GIS) and initiated a surveying process with the support of UN-Habitat.

The outcome of the process was the development of a detailed database and mapping of the geographical area of the UoM, which is continuously updated and currently used to guide present and future projects. Today, the RTO consists of a surveying engineer and two agricultural engineers and Jabal Amel UoM is planning to employ an urban planner. The office relies on galvanizing and engaging local expertise, a major contributing factor to the RTOs success.

The RTO is supported by UoM staff in various planning, data management, and municipal service activities. The unit managed to expand its scope of work from physical development to community development, data management, project implementation, monitoring urban sprawl/development, followup, and planning. Today, the UoM is focused on agricultural development and addresses educational, cultural, and social development. In terms of agricultural development, the RTO gathered data on the agricultural sector, which served as a basis for the Union to provide local farmers with incentives to invest in the agricultural sector.

Jabal Amel UoM is currently developing a strategic plan. According to the mayor, this will not be a difficult task since information available in the database developed by the RTO will provide them with the necessary knowledge. With the RTO's support, the UoM also coordinates the role of international organizations active in the area. Another key RTO function is providing assistance to municipalities in conducting studies for municipal projects to be presented to the relevant ministry, in order to receive 
funds for implementation and development. The UoM considers the RTO unit to be a major support system for technical and well-informed, sound decisions.

\subsection{The UoM of Sahel Zahrani:}

Through the UN-Habitat program responding to the Syrian refugee crisis, the Sahel Zahrani RTO has been supporting the UoM in the area since its establishment in October 2013. The office is involved in data collection, mapping, conducting studies, and monitoring. It also responds to the needs the municipalities and provides input regarding proposed projects, as well as being the coordinator of implementation of UN-Habitat projects related to shelter and infrastructure. The RTO currently consists of a head of RTO, Engineer, Engineering assistant, surveyor, and monitor.

According to the mayor, the office has been busy focusing on the rehabilitation of houses for Syrian refugees and implementation of UN-Habitat's project. Thus, it has not yet used its full capacity in planning and supporting municipal projects. The office has proved to be efficient, namely due to the great support of the mayor, and because the RTO team members are from the community. As one stated: "I am from the area and know it by heart." 10

Although the RTO is now playing an important role in emergency response through the rehabilitation of houses and infrastructure, the UoM is laying the foundation for its long term role and functions as a strategic unit for planning, through proposing a strategic vision for the area, in partnership with local universities and UN-Habitat. Furthermore, the RTO contributed to strengthening the role of the union in coordinating international and national organizational response to the Syrian refugee crisis. Bi-weekly coordination meetings ensure that interventions are in line with the UoM vision and that projects do not overlap. The mayor maintained that the RTO will still function as an intrinsic unit within the UoM after the UN-Habitat project ends. 11

\section{Assets and Challenges}

UN-Habitat's experience of working through Unions of Municipalities since 2007 demonstrates the great potential of UoMs in supporting development on the regional level - as in the case of Jabal Amel and Sahel Zahrani. However, key challenges remain and could be summarized as follows.

Data Management and Consultation: The lack of detailed and updated data in public institutions and governmental agencies in Lebanon is an obstacle to guiding sustainable development projects. Thus, supporting UoMs in data collection is key to guiding any intervention and lays the foundation for future planning. The introduction of the GIS Mapping at the level of municipal unions through RTOs proved to be vital to data collection and updated information. Furthermore, supporting unions with technical units and qualified experts is important to guide municipalities with limited financial and human resources on project planning and implementation.

Financial Capacities: UoMs usually have limited financial capacities. Their resources are often drained by responding to the basic needs of the local population, in terms of service provision and basic 
infrastructure provision. Hence, financial support to UoMs to maintain a level of qualified experts and increase their planning capacities is key.

International Organizations' Interventions: The Syrian emergency response encouraged various international donors to respond through UoMs and individual Municipalities in Lebanon, especially with the lack of trust on the level of the central government. Operational RTOs provided a key contribution to UoMs in coordinating the humanitarian intervention of international and national organizational through bi-weekly coordination meetings, among other measures.

Lack of Long-term Visions: Many RTOs are constrained in their scope of work, especially with the lack of long-term visions and plans at the UoM and municipal levels. Through UoMs, RTOs have the capacity to contribute to planning and decision-making at a regional level. However, as the mayor of Sahel al-Zahrani stated: "RTOs are confined at times to responding to the Unions' decisions and immediate needs, when the RTO should be playing a key role in guiding the Unions towards planning for the future." 12

Community Integration and Municipal Engagement: RTOs work closely with municipalities and communities for data collection and project support. This allows the unit to create strong and sustainable relationships with the community, facilitating the work of UoMs. The unit consists of local staff, which facilitates community integration. For example, the RTO engineer in Sahel Zahrani highlighted that being from the area facilitates his work, especially since he knows the area "by heart." While the top-down approach in decision making on the level of the UoM could be a challenge for community participation, still, RTOs have the potential to link the community with the UoM.

Management and Human Resource Capacities: Ensuring efficient management of the technical unit within UoMs is necessary to ensure its sustainability. This should be addressed in the introduction of any unit at the level of the Union. Furthermore, UoMs operate on a large regional scale and have thus shown the need for qualified experts to guide their work and interventions.

\section{Conclusion}

Municipalities and Unions of Municipalities in Lebanon have proven to be active local authorities, with key assets to tap into towards contributing to long-term planning on a regional and national level. However, they possess limited financial and administrative capacities, which restrain their potential to respond to large-scale emergencies or to plan for the future. This is particularly evident today with the Syrian refugee crisis, where several unions and municipalities were suddenly faced with the urgent demand to assist refugees, who sometimes constitute more than half the local population.

Mayors and communities were perplexed and torn between the needs of the local population and the emergent needs of refugees. Unions and municipalities were overwhelmed with responding to the health, education, infrastructure provision, security, and livelihoods of a new population, on top of addressing the rising tensions between host communities and refugees. 
Most international donors considered unions and municipalities to be among the best local partners in their intervention to support the crisis, which shows the potential of these local authorities to address semi-urban and urban issues and plan for the future, despite the lack of a national policy

The RTO model presented in this paper provides an example of the importance of working in a strategic manner to enhance capacities at the municipal level to respond to emergencies, in addition to planning and community development. This model could be more efficient with more detailed follow-up and training of UoMs in terms of planning. Thus, support should be provided to UoMs as well as enhancing their capacities to respond to emergencies and eventually plan for the future, especially in a context where the government remains arguably passive in responding to a crisis, which impacted Lebanon on every level.

\section{Bibliography:}

Samir El Daher, December 2013, "The Impact of the Syrian Conflict on the Lebanese Economy" Roundtable at Lebanese Center for Policy Studies, Beirut.

Aicha Mouchref, 2008, "Forgotten Akkar. Socio-Economic Reality of the Akkar Region", Mada Association, Beirut.

Karim El Mufti, 2014, "Official response to the Syrian refugee crisis in Lebanon, the disastrous policy of no-policy", Civil Kociety Knowledge Center, Lebanon Support, [ONLINE]: https://civilsociety-centre.org/paper/official-response-syrian-refugee-crisis-lebanondisastrous-policy-no-policy

Rabih Shibli, 2014, "Reconfiguring Relief Mechanisms: The Syrian Refugee Crisis in Lebanon," Refugee Research and Policy in the Arab World Program, Research Report, Issam Fares Institute for Public Policy and International Affairs. American University of Beirut. https://www.aub.edu.lb/ifi/public_policy/pal_camps/Documents/research_reports/20140224ifi_pc_unrwa .pdf Last accessed 10 March 2014

UNHCR, 2013, "2014 Syria Regional Rense Plan," http://www.unhcr.org/syriarrp6/docs/Syria-rrp6-full-report.pdf. Last accessed 20 February 2014

UNHCR, Syria Regional Refugee Response Inter-agency Information Sharing Portal, 2014, http://data.unhcr.org/syrianrefugees/country.php?id=122. Last accessed 3 April 2014 
Éric Verdeil, Ghaleb Faour, Sébastien Velut, 2007, Atlas du Liban : Territoires et société. Nouvelle édition, Beyrouth, Liban, Presses de l'Ifpo.

Leila Zakharia, Sonya Knox, 2014, "The international aid community and local actors: Experiences and testimonies from the ground", Civil Society Knowledge Center, Lebanon Support, [ONLINE]:http://civilsociety-centre.org/paper/international-aid-community-and-local-actors

- 1. UNHCR, 2013, "2014 Syria Regional Response

Plan" http://www.unhcr.org/syriarrp6/docs/Syria-rrp6-full-report.pdf. Last accessed 20 February 2014.

- 2. Regions that are historically characterized by widespread poverty and chronic neglect of the Lebanese state. This has been the object of several publications undertaken by NGOs or academics. To read more see: Aicha Mouchref, 2008, "Forgotten Akkar. Socio-Economic Reality of the Akkar Region", Mada Association, Beirut. Éric Verdeil, Ghaleb Faour, Sébastien Velut, 2007, Atlas du Liban : Territoires et société. Nouvelle édition, Beyrouth, Liban, Presses de l'Ifpo. [Ed.]

- 3. Samir ElDaher, December 2013, "The Impact of the Syrian Conflict on the Lebanese Economy" Roundtable at Lebanese Center for Policy Studies, Beirut.

- 4. Karim El Mufti, 2014, "Official response to the Syrian refugee crisis in Lebanon, the disastrous policy of no-policy", Civil Society Knowledge Center, Lebanon Support, [ONLINE]: http://civilsociety-centre.org/paper/official-response-syrian-refugee-crisis-lebanondisastrous-policy-no-policy. Last accessed 24 Jan 2014.

- 5. Idem. - 6.UNHCR, Syria Regional Refugee Response Inter-agency Information Sharing Portal, 2014,

- 7. Rabih Shibli, 2014, "Reconfiguring Relief Mechanisms: The Syrian Refugee Crisis in Lebanon," Refugee Research and Policy in the Arab World Program, Research Report, Issam Fares Institute for Public Policy and International Affairs. American University of Beirut. https://www.aub.edu.lb/ifi/public_policy/pal_camps/Documents/research_reports/20140224ifi_pc unrwa.pdf Last accessed 10 March 2014. A 'Roadmap of Priority Interventions for Stabilization from The Syrian Conflict' has been adopted by the Lebanese Government with the support of the World Bank and UN in late 2013. For more info, please refer to: UNHCR, 2014 Syria Regional Response Plan Lebanon. Available on http://www.unhcr.org/syriarrp6/docs/syria-rrp6-lebanon-response-plan.pdf Last accessed 30 June 2014

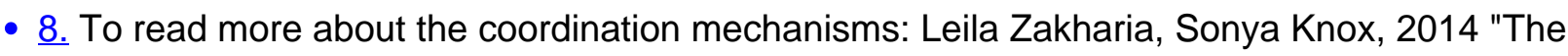
international aid community and local actors: Experiences and testimonies from the ground", Civil Society Knowledge Center, Lebanon Support,[ONLINE]:http://civilsociety-centre.org/paper/international-aid-community-and-localactors, accessed on June 25th 2014.

- 9. Interview with Dr. Mona Fawaz, 20 January 2014.

- 10. Interview with Technical Director of RTO, February 2014. 
- 11. Interview with Mayor of UoM of Sahel El Zahrani, February 2014.

- 12. Interview with Mayor of UoM of Sahel El Zahrani, February 2014. 